\title{
Drought-induced embolism in current-year shoots of two Mediterranean evergreen oaks
}

\author{
Clara A. Pinto ${ }^{\mathrm{a}, *}$, Jorge S. David ${ }^{\mathrm{b}, \mathrm{d}}$, Hervé Cochard ${ }^{\mathrm{c}}$, Maria C. Caldeira ${ }^{\mathrm{b}, \mathrm{d}}$, Manuel O. Henriques ${ }^{\mathrm{b}, \mathrm{d}}$, \\ Teresa Quilhó $^{\text {e,d }}$, Teresa A. Paço ${ }^{\text {b,f }}$, João S. Pereira ${ }^{\text {b,d }}$, Teresa S. David ${ }^{\text {a,d }}$ \\ a Instituto Nacional de Investigação Agrária e Veterinária, I.P., Quinta do Marquês, Av. da República, 2780-159 Oeiras, Portugal \\ ${ }^{\mathrm{b}}$ Instituto Superior de Agronomia, Technical University of Lisbon, Tapada da Ajuda, 1349-017 Lisboa, Portugal \\ ${ }^{c}$ INRA, UMR 547 PIAF, F-63100 Clermont-Ferrand, France \\ ${ }^{\mathrm{d}}$ Centro de Estudos Florestais, Tapada da Ajuda, 1349-017 Lisboa, Portugal \\ e Centro das Florestas e Produtos Florestais, Instituto de Investigação Científica Tropical, Tapada da Ajuda, 1349-017 Lisboa, Portugal \\ ${ }^{\mathrm{f}}$ Centro de Engenharia dos Biossistemas, Tapada da Ajuda, 1349-017 Lisboa, Portugal
}

\section{A R T I C L E I N F O}

\section{Article history:}

Received 14 April 2012

Received in revised form 3 August 2012

Accepted 4 August 2012

Available online 1 September 2012

\section{Keywords:}

Quercus suber

Quercus ilex

Vulnerability curves

Hydraulic conductivity

Xylem anatomy

Hydraulic safety margins

\begin{abstract}
A B S T R A C T
Quercus suber and Quercus ilex trees are major elements of Mediterranean landscapes, which are threatened by the increasing water deficits related to climate change. To contribute to the understanding of the capacity of these oaks to withstand severe drought we assessed the vulnerability to xylem embolism and the anatomical traits in current-year shoots. Data were collected in mature trees at two sites, in central/coastal and southern/inland Portugal. In situ safety margins to hydraulic failure were evaluated from long-term predawn and midday leaf water potential records. Results showed that xylem vulnerability to embolism was similar in $Q$. ilex and $Q$. suber. The $50 \%$ loss in hydraulic conductivity $\left(\Psi_{x y l, 50 P L C}\right)$ was observed at xylem water potentials of -2.9 and $-3.2 \mathrm{MPa}$ in shoots of $Q$. suber and $Q$. ilex, respectively. Values of mean vessel diameter of $Q$. suber shoots at both sites suggest an intra-species adaptation to the local water availability, with larger vessels at the more mesic site. In situ hydraulic safety margins observed in shoots showed that, even during the driest periods, both oaks lived comfortably above the most critical embolism thresholds. However, the hydraulic safety margins were narrower in the driest site. Results are relevant to the understanding of survival, growth, and functional behaviour of evergreen oaks in Mediterranean climates, under recurrent/seasonal drought conditions.
\end{abstract}

(c) 2012 Elsevier B.V. All rights reserved.

\section{Introduction}

In recent decades there were many reports of enhanced tree mortality rates in forests of all ages, especially in temperate regions (van Mantgem et al., 2009), but also in Mediterranean-type climates (Lloret et al., 2004). Plausible causes are increasing water deficits related to global warming (van Mantgem et al., 2009), which may result in the failure of the hydraulic system of trees (Ryan, 2011), associated or not to starvation and depletion of carbon reserves (McDowell et al., 2011). During dry periods water stress may induce xylem cavitation and the formation of embolisms, resulting in the disruption of water columns and in the reduction of water supply to leaves (Tyree and Zimmermann, 2002). Xylem embolism caused by severe drought stress has been

\footnotetext{
* Corresponding author. Tel.: +351 214463798; fax: +351 214463702.

E-mail addresses: clara.pinto@iniav.pt (C.A. Pinto), soaresdavid@isa.utl.pt (J.S. David), herve.cochard@clermont.inra.fr (H. Cochard), mcaldeira@isa.utl.pt (M.C. Caldeira),mhenriques@isa.utl.pt (M.O. Henriques), terisantos@isa.utl.pt (T. Quilhó), tapaco@isa.utl.pt (T.A. Paço), jspereira@isa.utl.pt (J.S. Pereira), teresa.david@iniav.pt (T.S. David).
}

considered one of the major factors affecting plant productivity and survival (Tyree and Sperry, 1988). Mediterranean-climate regions are characterised by recurrent droughts, with irregular/limited rainfall and high evaporative demand. Climate change scenarios for the Western Mediterranean Basin foresee warmer air temperatures and an increase in the length and intensity of the seasonal summer drought (Miranda et al., 2002). Trees cope with these seasonal water shortages by preventing water losses through stomatal closure and maximising the soil and groundwater uptake by deep roots (Canadell et al., 1996; David et al., 2007; Maherali et al., 2004). Under extreme drought, stomatal regulation may not be enough to maintain leaf water potential above a critical threshold and catastrophic embolism may occur (Sperry, 1986).

Mediterranean evergreen oak woodlands (montados in Portugal and dehesas in Spain) characterise the landscape of extensive areas of the Iberian Peninsula and are ecosystems of a high socioeconomic and conservation value (Bugalho et al., 2011). In CentralSouthern Portugal, Quercus suber L. (cork oak) and Quercus ilex spp. rotundifolia Lam. syn. ballota (holm oak) are the dominant 
species. Although co-occurring in some places, $Q$. ilex prevails in the inner, drier regions and $Q$. suber in the wetter, coastal and montane areas. This geographic distribution, though influenced by human activity, seems to mainly reflect the lesser drought resistance of $Q$. suber (David et al., 2007). Extensive literature is available concerning the xylem vulnerability to embolism and other hydraulic traits of Q. ilex (Corcuera et al., 2004; Gartner et al., 2003; Limousin et al., 2010; Lo Gullo and Salleo, 1993; Martínez-Vilalta et al., 2002; Tognetti et al., 1998; Villar-Salvador et al., 1997) and of other Mediterranean species (Iovi et al., 2009). However, Q. suber has been much less studied (Lo Gullo et al., 2003; Tyree and Cochard, 1996; Vaz et al., 2012). To our knowledge, its vulnerability to drought-induced embolism has not yet been fully characterised particularly in adult trees.

We aimed to evaluate and compare the xylem conducting efficiency and vulnerability of current-year shoots of $Q$. suber and $Q$. ilex to drought induced cavitation. Measurements and sampling were done in mature trees at two different sites, located in Central (Lezirias) and Southern (Mitra) Portugal. Cork oak was studied at Lezirias and Mitra whereas holm oak was only studied at Mitra. We hypothesised that: (1) Q. ilex xylem would be less prone to hydraulic failure than $Q$. suber, and the difference would be enough to explain the geographic distribution of the two species; (2) Differences in site water availability might reflect in small intra-species variations in the vulnerability to embolism and xylem anatomy. The specific objectives of this work were to: (1) measure xylem vulnerability to embolism in current-year shoots of mature cork and holm oak trees; (2) test intra-species differences in vulnerability to embolism and xylem anatomy of cork oak shoots between sites; (3) evaluate if species are living close to their hydraulic limits, by estimating the in situ minimum safety margins.

\section{Material and methods}

\subsection{Study sites and plant material}

The study was carried out at two evergreen oak woodlands $90 \mathrm{~km}$ apart, in Central (Lezirias site) and Southern (Mitra site) Portugal. The Mitra site $\left(38^{\circ} 32^{\prime} \mathrm{N}, 8^{\circ} 00^{\prime} \mathrm{W}\right)$ has an inland location near the town of Évora, at the "Herdade da Alfarrobeira" (ca. $150 \mathrm{~km}$ South-East of Lisbon), in a sparse mixed stand where $Q$. ilex dominates and $Q$. suber occurs in scattered patches. At this site two single species plots ( $150 \mathrm{~m}$ apart) were established. The soil is a $1 \mathrm{~m}$ deep Dystric Cambisol (FAO, 1988), with low water retention capacity, overlying a granite bedrock. The Lezirias site $\left(38^{\circ} 50^{\prime} \mathrm{N}\right.$, $8^{\circ} 49^{\prime} \mathrm{W}$ ) is located near the coast, at the estate of "Companhia das Lezirias", about $50 \mathrm{~km}$ East of Lisbon, in a pure Q. suber stand. The soil is a deep Arenosol (FAO, 1988), with high permeability and low water retention capacity, overlying a thick clay layer at ca. $9 \mathrm{~m}$ depth. The climate is Mediterranean at both sites, with hot dry summers and wet mild winters. Rainfall occurs predominantly from October to April. Long-term (1951-1980) mean annual rainfall and open water evaporation are 665 and $1760 \mathrm{~mm}$ for Mitra (the more xeric site), and 708 and $1347 \mathrm{~mm}$ for Lezirias, respectively (INMG, 1991a, 1991b). Mean annual temperature is $15.0^{\circ} \mathrm{C}$ at Mitra, ranging from $8.6^{\circ} \mathrm{C}$ in January to $23.1^{\circ} \mathrm{C}$ in August, and $15.6^{\circ} \mathrm{C}$ at Lezirias, ranging from $9.9^{\circ} \mathrm{C}$ in January to $22.0^{\circ} \mathrm{C}$ in $\mathrm{Au}-$ gust (INMG, 1991a, 1991b).

Hydraulic and anatomy measurements were done in 20072008 on four mature trees per species and site. Mean morphometric data of the sampled trees are given in Table 1. Tree age is about 60 years at Lezirias and $70($ Q. ilex $)-80$ (Q. suber) years at Mitra. Average annual growth of current-year shoots was $5 \mathrm{~cm}$ and 3$4 \mathrm{~cm}$ for $Q$. ilex and $Q$. suber at Mitra, respectively, and 7-20 cm for $Q$. suber at Lezirias (Pinto et al., 2011). Branches of $Q$. suber were sampled from both sites, whereas branches of $Q$. ilex trees were
Table 1

Mean (standard deviation, SD) morphometric data of the four sampled trees ( $Q$. suber and $Q$. ilex) at the experimental sites.

\begin{tabular}{lllrl}
\hline Site & Species & DBH $(\mathrm{m})$ & Height $(\mathrm{m})$ & $\begin{array}{l}\text { Crown projected } \\
\text { area }\left(\mathrm{m}^{2}\right)\end{array}$ \\
\hline Lezirias & Q. suber & $0.73(0.18)$ & $12.82(1.16)$ & $208.1(32.4)$ \\
Mitra & Q. suber & $0.49(0.04)$ & $9.05(0.44)$ & $128.7(25.8)$ \\
Mitra & Q. ilex & $0.40(0.05)$ & $7.63(0.48)$ & $60.2(20.2)$ \\
\hline
\end{tabular}

$\mathrm{DBH}$ is diameter at breast height.

only sampled from the Mitra site. In situ leaf and xylem water potential measurements were done in the same trees used for branch sampling.

\subsection{Environmental variables}

Solar radiation (CM6B, Kipp and Zonen, Delft, The Netherlands) and rainfall (tipping-bucket rain gauge recorder ARG100, Environmental Measurements, Gateshead, UK) were measured at both sites (2001-2003 at Mitra and 2006-2008 at Lezirias). Water table depth was also measured at both sites by pressure transducers (PDCR 830, Campbell Scientific) installed in boreholes. Data were recorded every $10 \mathrm{~s}$ and stored as 10 or $30 \mathrm{~min}$ averages or totals by CR10X data loggers (Campbell Scientific, Shepshed, UK).

\section{3. "In situ" leaf water potentials}

Leaf water potential ( $\Psi_{l}$, MPa) was measured monthly at Mitra (2001-2003 for both plots) and Lezirias (2006-2008). Measurements were done in four mature trees per plot at predawn $\left(\Psi_{l, p d}\right)$ and around midday $\left(\Psi_{l, m d}\right)$, using a Scholander pressure chamber (PMS 1000, PMS Instruments, Corvalis, Oregon, USA) (Scholander et al., 1965). At each sampling time, three to four leaves per tree were collected at similar heights from the South-facing part of the crowns, bagged, and immediately measured.

\subsection{Vulnerability to xylem embolism}

The degree of vulnerability to embolism was inferred from vulnerability curves (VCs), plotting the xylem water potential $\left(\Psi_{x y l}\right.$, $\mathrm{MPa}$ ) versus the corresponding percentage loss of hydraulic conductivity (PLC, \%). We used the dehydration technique (Sperry, 1986; Sperry et al., 1988), considered as the most reliable (reference technique) (Choat et al., 2010; Cochard et al., 2005; Sperry et al., 2012)

The hydraulic conductivity $\left(K_{h}, \mathrm{~kg} \mathrm{~s}^{-1} \mathrm{MPa}^{-1} \mathrm{~m}\right)$ of shoot segments of both species was measured following Sperry et al. (1988), with a high precision flow meter, XYL'EM (Embolism Meter, Bronkhorst, Montigny-Les-Cormeilles, France). $K_{h}$ was measured at low pressure $\left(2-3 \times 10^{-3} \mathrm{MPa}\right)$, to minimise the displacement of air bubbles in open vessels. All segments were perfused with ultra-pure, deionized, degassed and filtered $(0.2 \mu \mathrm{m})$ water with $10 \mathrm{mM} \mathrm{KCl} . K_{h}$ was calculated as the ratio between the flow through each segment and the corresponding hydrostatic pressure gradient. It was converted to specific hydraulic conductivity $\left(K_{s}, \mathrm{~kg} \mathrm{~s}^{-1} \mathrm{MPa}^{-1} \mathrm{~m}^{-1}\right)$ by dividing by the xylem cross-sectional area $\left(\mathrm{m}^{2}\right)$.

Prior to branch collection, the maximum length of xylem vessels was determined using the air infiltration method in the entire length of large branches (Zimmermann and Jeje, 1981). The longest vessels in $Q$. suber and $Q$. ilex stems were found to be 2.6 and $2.0 \mathrm{~m}$, respectively. Hence, to avoid contamination by air entry upon cutting, only branches longer than $3 \mathrm{~m}$ were sampled, overnight, from the top third of the South-facing side of the crowns. At each sampling date, one or two large branches per tree (depending on crown 
size) were harvested and immediately bagged to minimise dehydration. Once in the laboratory, branches were gradually dehydrated to cover a wide range of $\Psi_{x y l}$ values. For each $\Psi_{x y l}$ point (measured in previously covered leaves), PLC values were obtained from 3 to 6 terminal, and non-contiguous current-year shoots. On average, 20 current-year shoots were sampled per branch. After measuring $\Psi_{x y l}$, shoots with a diameter of $2-3 \mathrm{~mm}$ were excised underwater, trimmed to approximately $2.5 \mathrm{~cm}$ length, and the initial hydraulic conductivity $\left(K_{h, i n}\right)$ was measured. Segments were repeatedly perfused (pressure of ca. $0.15 \mathrm{MPa}$ ) to dissolve and expel air bubbles, until the maximum conductivity $\left(K_{h, \max }\right)$ was obtained. The degree of embolism (PLC, \%) was estimated based on $K_{h, \text { in }}$ and $K_{h, \max }$ (Sperry et al., 1988). Only current-year shoots were used for conductivity measurements to prevent previously embolized and non-functional conduits of older xylem rings from contributing to PLC estimates. Sample size was restrained by the average length of current-year shoots of $Q$. suber at Mitra. Quercus species are known to have very long vessels and, hence, it is likely that some samples had open-cut vessels at both ends. However, sample length should not impose a methodological problem to vulnerability estimates (i.e., overestimation) since PLC values are ratios of conductivities.

Vulnerability curves (VCs) were fitted using the exponential sigmoid equation proposed by Pammenter and Vander Willigen (1998):

$P L C=\frac{100}{1+e^{a\left(\Psi_{x y l}-b\right)}}$

where $\Psi_{x y l}(\mathrm{MPa})$ is the measured xylem water potential; $a$ is related to the slope of the curve and $b$ is the $\Psi_{x y l}$ at which a $50 \%$ loss in hydraulic conductivity occurs $\left(\Psi_{\text {xyl,50PLC }}\right)$. Although there are other functional options to fit the VCs (Ogle et al., 2009) we decided to use the Pammenter and Vander Willigen (1998) equation since it is simple, widely used, and parameters have an inherent physiological meaning (under the air-seeding hypothesis, Tyree and Zimmermann (2002)).

Three vulnerability curves were constructed: two for $Q$. suber, one for each site, and one for Q. ilex, for the Mitra site. Each VC was adjusted using at least 25 points per species/site.

A modified version of Eq. (1) was also fitted to the $\mathrm{PLC} / \Psi_{x y l}$ dataset to account for a non-zero "native" level of embolism $\left(P L C_{n a t}\right)$ :

$P L C=P L C_{n a t}+\frac{100-P L C_{n a t}}{1+e^{a_{1}\left(\Psi_{x y l}-b_{1}\right)}}$

$\Psi_{x y l, 50 P L C}$ values obtained from Eqs. (1) and (2) were used to assess the possible impact of $P L C_{\text {nat }}$ on vulnerability estimates.

The xylem tension/pressure values causing 50\% ( $\left.\Psi_{x y l, 50 P L C}\right), 75 \%$ ( $\left.\Psi_{x y l, 75 P L C}\right)$ and complete loss of conductivity $\left(\Psi_{x y l, 99 P L C}\right)$ were used to establish the hydraulic safety margins.

\subsection{Xylem anatomy}

Vessel inner diameter was measured on a sub-sample of the segments used for the vulnerability curves (three segments per tree). Transverse sections (ca. $20 \mu \mathrm{m}$ thick) were obtained using a sledge microtome (Leica SM2400, Leica Microsystems GmbH, Nussloch, Germany), stained with safranine (1\%) for 1-3 min, and mounted with glycerine Kaiser. Cross sections were viewed in a light microscope system (Leica CTR Mic) interfaced with a digital camera (Leica DM LA, Leica Microsystems, Heerbrugg, Switzerland) at $10 \times 10 \times 2$. Two sectors, located $90-180^{\circ}$ apart, from the outermost rings of each transverse section were sampled. Within each sector, the cross-sectional inner diameters of all open vessels $(\mu \mathrm{m})$ were measured using the image analysis software Leica QWin Plus V. 3.5.0 (Leica Microsystems, Heerbrugg, Switzerland).
The following variables were considered to describe xylem anatomy: mean vessel diameter $\left(D_{\text {mean }}, \mu \mathrm{m}\right)$, vessel density (number of vessels $\mathrm{mm}^{-2}$ ), and conductive area (percentage of cross-sectional area occupied by vessels). A theoretical hydraulic conductivity, $K_{h, t}\left(\mathrm{~kg} \mathrm{~s}^{-1} \mathrm{MPa}^{-1} \mathrm{~m}\right)$ was calculated for each section, from the anatomy data, following the Hagen-Poiseuille equation (Sellin et al., 2008; Sperry et al., 1994; Tyree et al., 1994; Tyree and Zimmermann, 2002):

$K_{h, t}=(\pi \rho / 128 \eta) \sum_{i=1}^{n} D_{i}^{4}$

where $\rho$ is density of water $\left(1000 \mathrm{~kg} \mathrm{~m}^{-3}\right), \eta$ is the dynamic viscosity of water $\left(10^{-9} \mathrm{MPa}\right.$ at $\left.20^{\circ} \mathrm{C}\right)$ and $D$ is the diameter of the $i$ vessel (m). To characterise the xylem conducting efficiency per unit of sapwood area, the theoretical specific hydraulic conductivity, $K_{s, t}$ $\left(\mathrm{kg} \mathrm{s}^{-1} \mathrm{MPa}^{-1} \mathrm{~m}^{-1}\right)$, was determined by dividing the estimated $K_{h, t}$ by the sample cross-sectional xylem area $\left(\mathrm{m}^{2}\right)$. We also calculated the vessel diameter frequency in $5 \mu \mathrm{m}$ diameter classes and estimated the relative contribution of each diameter class to the predicted $K_{h, t}$ of each segment (Tyree et al., 1994). A hydraulically weighted mean diameter $\left(D_{h w}, \mu \mathrm{m}\right)$ was estimated for each segment as: $\left(\sum D_{i}^{5} / \sum D_{i}^{4}\right)$ (Sperry et al., 1994). The mean diameter of the vessels that account for $95 \%$ of the predicted $K_{h, t}, D_{95}$, was also estimated (Tyree et al., 1994).

\subsection{Estimation of shoot xylem water potential from "in situ" $\Psi_{l}$ measurements}

Daily courses of leaf and shoot xylem water potentials were done in two sunny summer days per plot. Measurements (four trees per species/site) started at dawn and were repeated every 2-3 h throughout the day. At each measurement time, three covered $\left(\Psi_{x y l}\right)$ and three sun exposed $\left(\Psi_{l}\right)$ leaves were measured.

As the number of direct shoot $\Psi_{x y l}$ measurements was restricted to two days per plot, we attempted to find a relationship to predict $\Psi_{x y l}$ from the available long-term $\Psi_{l}$ records. A linear regression between shoot xylem and leaf water potentials was found to be site-specific. Using the Darcy's law (e.g. Wullschleger et al., 1998) we developed a relationship between $\Psi_{x y l}$ and $\Psi_{l, p d}$ and $\Psi_{l}$ to tackle the mentioned difficulty. Water flow $(F)$ from soil or groundwater to the leaves can be described as:

$F=\frac{\Psi_{l, p d}-\Psi_{l}}{R_{\text {plant }}}$

where $R_{\text {plant }}$ is the total resistance in the soil to leaf pathway and $\Psi_{l, p d}$ is assumed as a surrogate of $\Psi_{\text {soil }}$. Considering only the flow path from the stem xylem to leaves, Eq. (4) may be re-written as:

$F=\frac{\Psi_{x y l}-\Psi_{l}}{R_{\text {petiole }}}$

where $R_{\text {petiole }}$ is the total resistance in the xylem-leaf pathway. Assuming steady-state conditions in the soil-leaf continuum, Eqs. (4) and (5) can be combined as:

$F=\frac{\Psi_{l, p d}-\Psi_{l}}{R_{\text {plant }}}=\frac{\Psi_{x y l}-\Psi_{l}}{R_{\text {petiole }}}$

Eq. (6) can be re-written as:

$\Psi_{x y l}=\left(\Psi_{l, p d}-\Psi_{l}\right) \frac{R_{\text {petiole }}}{R_{\text {plant }}}+\Psi_{l}$

Considering $\frac{R_{\text {petiole }}}{R_{\text {plat }}}$ as an approximate constant, $\alpha$, Eq. (7) can be re-arranged as:

$\frac{\Psi_{x y l}}{\Psi_{l, p d}}=\alpha+(1-\alpha) \frac{\Psi_{l}}{\Psi_{l, p d}}$ 
Data from both oaks fitted nicely to the linear relationship between $\Psi_{x y l} / \Psi_{l, p d}$ and $\Psi_{l} / \Psi_{l, p d}$ (Eq. (8)), irrespective of the site. Hence, we could predict minimum $\Psi_{x y l}$ of shoots under field conditions from the long-term $\Psi_{l, p d}$ and $\Psi_{l, m d}$ records. These values were then entered in the fitted vulnerability curves to establish the minimum hydraulic safety margins at which shoots of both species operate (Hacke et al., 2000; Pockman and Sperry, 2000).

\subsection{Statistical analyses}

The coefficients $a$ and $b$ of the fitted vulnerability curves were estimated using the non-linear regression procedure in the statistics software package PASW Statistic 18.0.0 (IBM Corporation, NY, USA) and the software package R 2.13.0 (The R Foundation for Statistical Computing, Vienna, Austria) using the "nls" function. The fitted coefficients $a$ and $b$ were compared between species/sites and tested with Student $t$-tests (Snedecor and Cochran, 1978; Zar, 1996).

Differences in mean vessel diameter, vessel density, conductive area and $K_{s}$, between trees, species and sites, were tested with Analyses of Variance. Linear mixed models were used, considering species/sites as fixed effects and tree within species as a random factor. These analyses were performed with the mixed procedure of SAS statistic software (SAS system 9.2, SAS Institute Inc., Cary, NC, USA) for a significance level of $5 \%(\alpha=0.05)$.

\section{Results}

\subsection{Environmental variables}

Fig. 1 shows the seasonal variation of solar radiation (MJ m${ }^{-2}$ month $^{-1}$ ) and rainfall $\left(\mathrm{mm} \mathrm{month}^{-1}\right.$ ) for the Lezirias and Mitra sites. During summer periods, radiation was high and rainfall usually scarce. Annual rainfall at Lezirias was 802.0, 441.5 and
$576.0 \mathrm{~mm}$, i.e. $13 \%$ above average in 2006 and 38\% and 19\% below average in 2007 and 2008, respectively. At Mitra, annual rainfall was $843.0,825.2$ and $706.4 \mathrm{~mm}$, i.e. $27 \%, 24 \%$ and $6 \%$ above average in the years between 2001 and 2003, respectively. Differences in rainfall distribution and amount reflect the variability typical of Mediterranean-type climates.

Water table depth varied from a minimum in winter/spring to a maximum in summer/autumn. During the studied years, it fluctuated between 1.3 and $4.5 \mathrm{~m}$ at Lezirias, and between 1.1 and $5.1 \mathrm{~m}$ at Mitra.

\section{2. "In situ" leaf water potentials}

Long-term variation in $Q$. suber $\Psi_{l, p d}$ differed between sites. At Lezirias, $\Psi_{l, p d}$ remained high (above $-0.45 \mathrm{MPa}$ ) (Fig. 2a), with no seasonal variation. At Mitra, where $Q$. suber and $Q$. ilex share the same habitat conditions, $\Psi_{l, p d}$ remained high during the wet periods, but strongly declined during the dry summer up to $-2.3 \mathrm{MPa}$ in $Q$. suber and $-1.7 \mathrm{MPa}$ in $Q$. ilex (Fig. 2b and c). At both sites, $\Psi_{l, m d}$ values varied according to atmospheric conditions. Absolute minimum for each species was about constant throughout the seasons and years and was lower in Q. ilex (-3.48 MPa) (Fig. 2c) than in Q. suber ( -2.98 and $-2.95 \mathrm{MPa}$ at Lezirias and Mitra, respectively) (Fig. 2a and b).

\subsection{Vulnerability to xylem embolism and maximum hydraulic conductivity}

The parameters of the VCs fitted through Eq. (1) are shown in Table 2 and Fig. 3. The xylem tension inducing 50\% loss of hydraulic conductivity $\left(\Psi_{x y l, 50 P L C}\right.$; parameter $b$ ) was $-2.9 \mathrm{MPa}$ for $Q$. suber (Table 2, Fig. 3a and b) and -3.2 MPa for Q. ilex (Table 2, Fig. 3c). Differences between parameters $a$ and $b$ for $Q$. suber and $Q$. ilex were statistically non-significant, either between species or sites (Table 2). The original VCs (Eq. (1)) showed "native" embolism

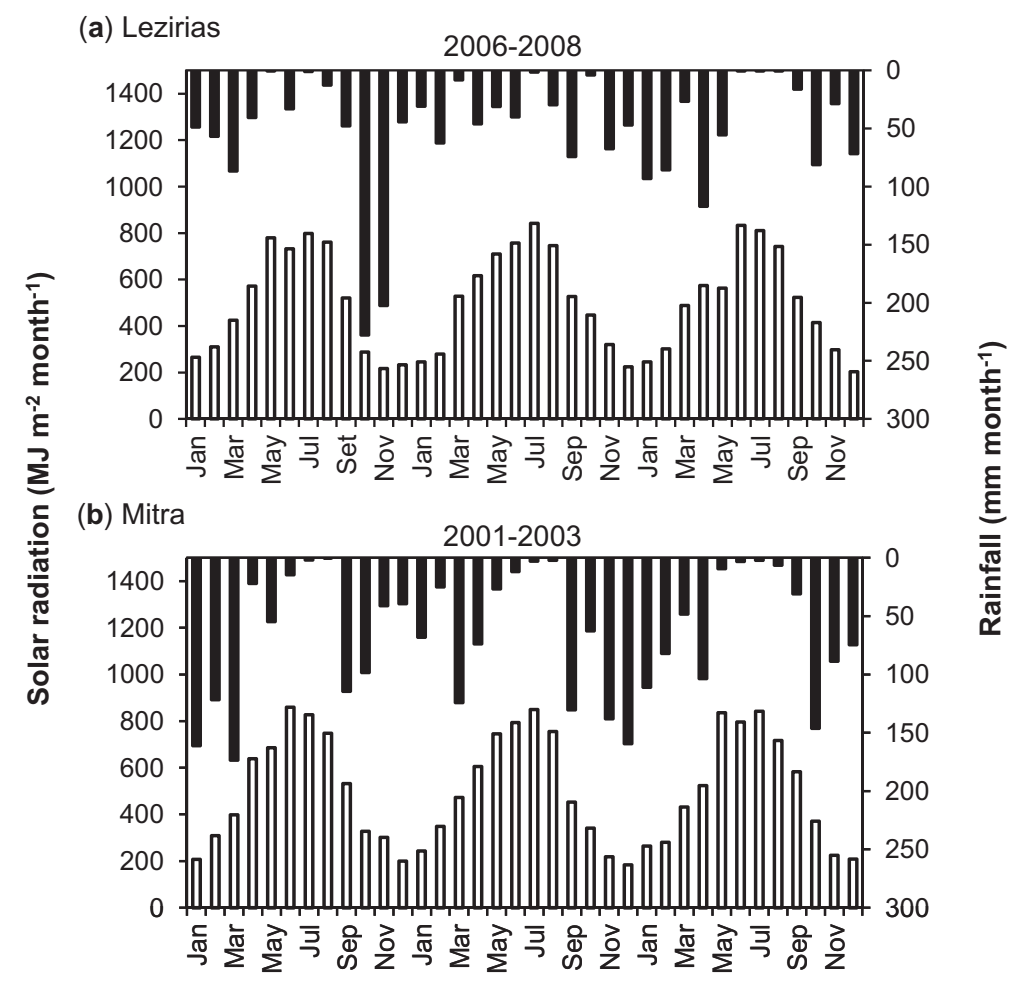

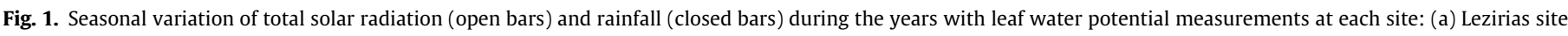
(2006-2008); (b) Mitra site (2001-2003). 
(a)

\section{Q. suber - Lezirias}

2006-2008

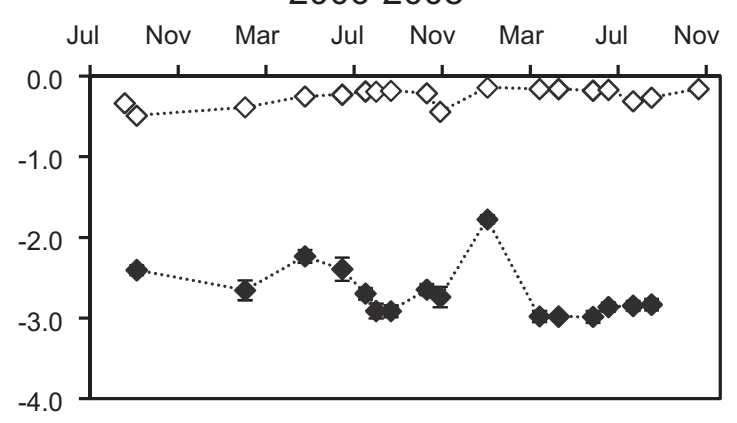

(b)

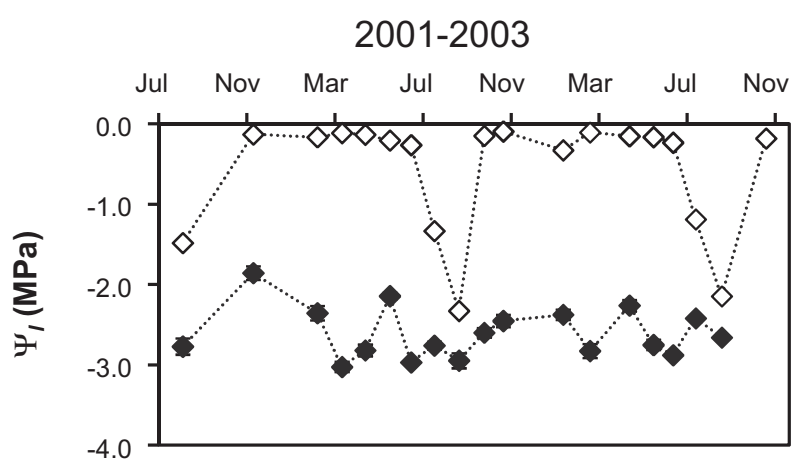

(c)

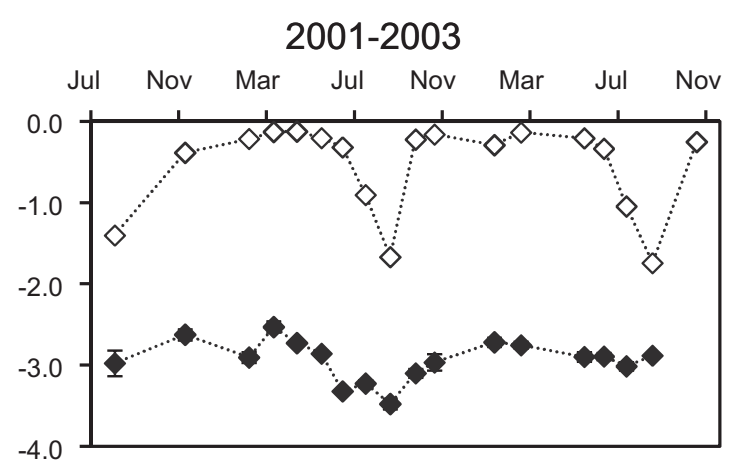

Fig. 2. Long-term seasonal variation of predawn (open symbols) and midday (closed symbols) leaf water potential in $Q$. suber (a and b) and $Q$. ilex (c) from the Lezirias (2006-2008) and Mitra (2001-2003) sites. Three to four leaves per tree were measured in four trees per species/site. Error bars are standard errors (contained within the size of the symbols in predawn leaf water potential). levels of around 20\% PLC. To account for the impact of a non-zero "native" level of embolism, a new VC (Eq. (2)) was fitted to each dataset. $\Psi_{x y l, 50 P L C}$ values for the two fitted curves were similar in all cases (Fig. 3).

Mean values of the measured maximum specific hydraulic conductivity $\left(K_{s}\right)$ were 1.38 and $1.03 \mathrm{~kg} \mathrm{~s}^{-1} \mathrm{MPa}^{-1} \mathrm{~m}^{-1}$ in shoots of $Q$. ilex and $Q$. suber, respectively (Table 2 ), but differences were not statistically significant, either between trees or species or sites.

\subsection{Xylem anatomy}

Current-year shoots of both species have solitary vessels with circular to elliptical cross sections, arranged in a diagonal to radial pattern (Fig. 4). The apparent ring limit visible in Fig. 4a corresponds to a pause in growth observed between the spring and summer shoot elongation periods. This growing pattern is frequently observed in Q. suber trees at the Lezirias site but not at Mitra (Pinto et al., 2011). No occluded vessels were observed in any of the species. $D_{\text {mean }}$ values of shoots were compared between trees within species/site: differences were not statistically significant. $D_{\text {mean }}$ values of shoot xylem for each species or site were $25.28 \pm 8.1 \mu \mathrm{m}$ and $22.21 \pm 7.4 \mu \mathrm{m}$ for $Q$. suber, at Lezirias and Mitra, respectively, and $25.61 \pm 8.3 \mu \mathrm{m}$ for $Q$. ilex at Mitra (Table 3). Differences between these values were only statistically significant for $Q$. suber shoots between sites $(P$-value $=0.0383)$, with larger vessels at the more mesic site (Lezirias).

Deviations between $D_{\text {mean }}$ and $D_{h w}$ were higher for shoots of $Q$. suber from Lezirias, reflecting a wider range of conduit diameters. $D_{95}$ was always higher (14-16\%) than $D_{\text {mean }}$ (Table 3 ), irrespective of the species. Vessel diameter distribution displayed a unimodal pattern, particularly for $Q$. suber (Fig. 5).

Mean vessel density and conductive area were similar between species and sites (Table 3 ).

As expected, maximum measured specific hydraulic conductivity $\left(K_{s}\right)$ was lower than the maximum theoretical hydraulic conductivity ( $K_{s, t}$, estimated from vessel anatomy). The ratio between mean values of $K_{s}$ and $K_{s, t}$, an estimate of xylem conducting efficiency, was similar for shoots of both species and sites: $57 \%$ for $Q$. ilex and $52 \%$ and $59 \%$ for $Q$. suber shoots, at Lezirias and Mitra, respectively. About $90 \%$ of the total theoretical hydraulic conductivity was sustained by vessels with diameters wider than $20 \mu \mathrm{m}$ in both species.

\section{5. "In situ" xylem water potentials and minimum safety margins above embolism thresholds}

The differences between leaf and shoot xylem water potentials during summer sunny days were more pronounced at Lezirias than at Mitra, due to the higher $\Psi_{l, p d}$ at Lezirias (Fig. 6). Daily minimum $\Psi_{l}$ for $Q$. suber was approximately $-3.0 \mathrm{MPa}$ at both sites (Fig. 6a

Table 2

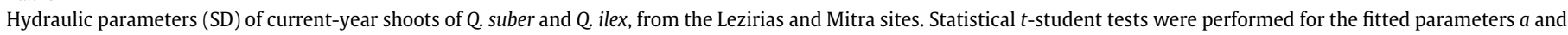

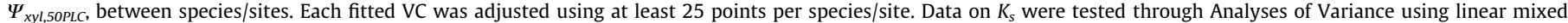

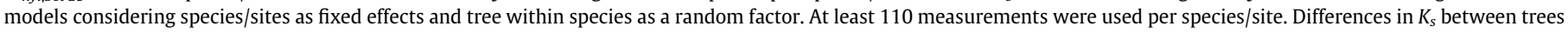
within species/site were statistically non-significant. Statistics are not given for $\Psi_{x y l, 75 P L C}$ and $\Psi_{x y l, 99 P L C}$ (estimated parameters).

\begin{tabular}{|c|c|c|c|c|c|}
\hline \multirow[b]{2}{*}{ Parameters } & \multicolumn{2}{|l|}{ Q. suber } & \multicolumn{3}{|l|}{ Q. ilex } \\
\hline & $\begin{array}{l}\text { Lezirias } \\
\text { (A) }\end{array}$ & $\begin{array}{l}\text { Mitra } \\
\text { (B) }\end{array}$ & $\begin{array}{l}\text { Mitra } \\
(\mathrm{C})\end{array}$ & $(\mathrm{A}$ and $\mathrm{B})$ & (B and C) \\
\hline$\Psi_{x y l, 50 P L C}(\mathrm{MPa})$ & $-2.89(2.0)$ & $-2.94(1.6)$ & $-3.21(1.3)$ & ns & ns \\
\hline$a$ & $0.50(0.07)$ & $0.47(0.05)$ & $0.38(0.02)$ & ns & ns \\
\hline$K_{\mathrm{s}}\left(\mathrm{kg} \mathrm{s}^{-1} \mathrm{MPa}^{-1} \mathrm{~m}^{-1}\right)$ & $1.03(0.56)$ & $1.03(0.31)$ & $1.38(0.42)$ & ns & ns \\
\hline$\Psi_{x y l, 75 P L C}(\mathrm{MPa})$ & -5.09 & -5.28 & -6.10 & & \\
\hline$\Psi_{x y l, 99 P L C}(\mathrm{MPa})$ & -12.08 & -12.72 & -15.30 & & \\
\hline
\end{tabular}

ns: non-significant. 
Quercus suber

Lezirias

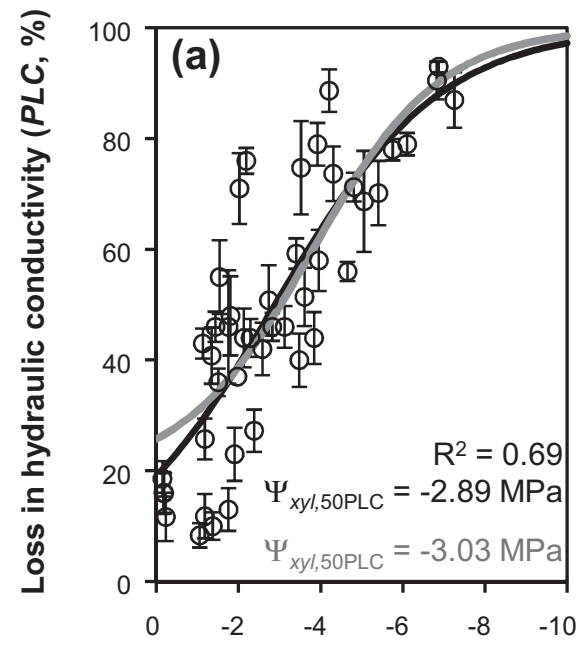

Mitra

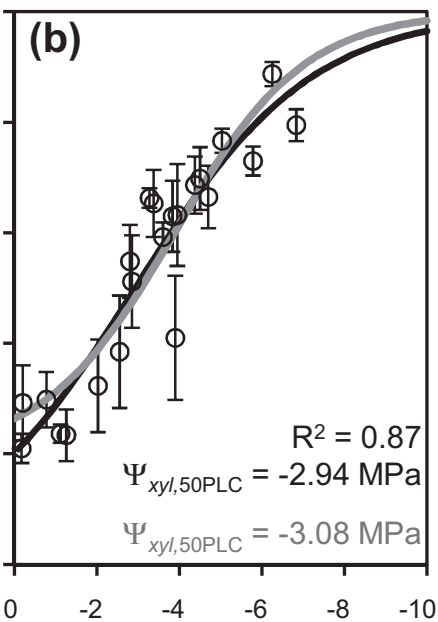

Quercus ilex

Mitra

Xylem water potential $\left(\Psi_{x y l}, \mathrm{MPa}\right)$

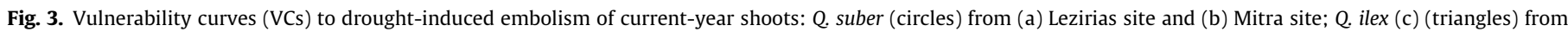

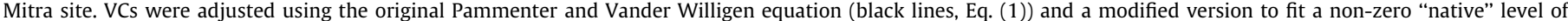

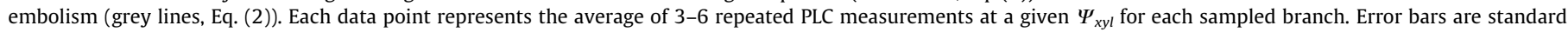

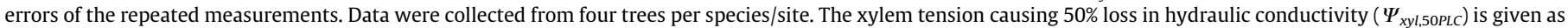
inserts (black: original version; grey: modified version).
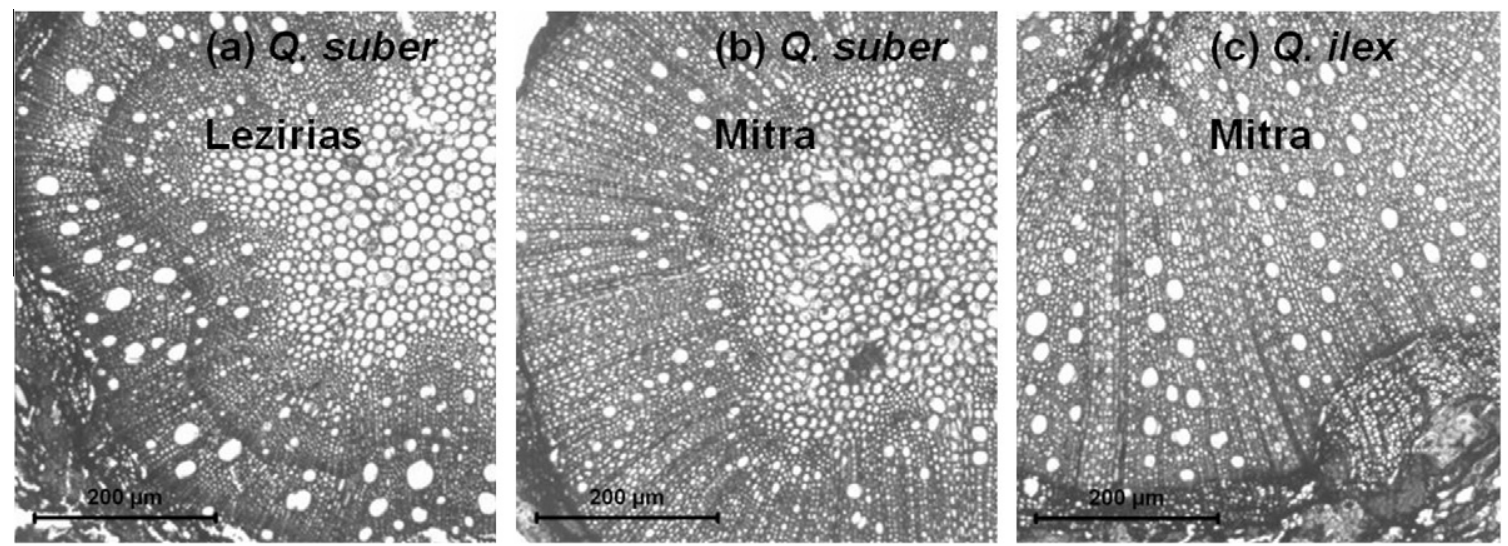

Fig. 4. Microscope images of shoot xylem of $Q$. suber from the Lezirias (a) and Mitra (b) sites and Q. ilex (c) from Mitra site. Scale bars represent $200 \mu \mathrm{m}$.

and b), similar to the absolute lowest seasonal $\Psi_{l, m d}$ for $Q$. suber (Fig. 2a and b). For $Q$. ilex at Mitra, daily minimum $\Psi_{l}$ was $-3.2 \mathrm{MPa}$ (Fig. 6c), also within the range of the observed lower values of seasonal $\Psi_{l, m d}$ (Fig. 2c). Daily minimum $\Psi_{x y l}$ of shoots were -1.5 and $-2.4 \mathrm{MPa}$ for $Q$. suber at Lezirias and Mitra, respectively, and $-2.3 \mathrm{MPa}$ for Q. ilex (Fig. 6).

Based on the relationships of Fig. 7 (Eq. (8)), we could predict $\Psi_{x y l}$ of shoots from the long-term $\Psi_{l, m d}$ and $\Psi_{l, p d}$ data (Fig. 2), both for Q. suber (Lezirias and Mitra sites) and Q. ilex (Mitra site). For the whole study period, predicted absolute minimum $\Psi_{x y l}$ of $Q$. suber shoots was $-1.5 \mathrm{MPa}$ at Lezirias and $-2.5 \mathrm{MPa}$ at Mitra. For Q. ilex shoots, predicted absolute minimum $\Psi_{x y l}$ was $-2.4 \mathrm{MPa}$ (Mitra). Entering these values in the derived vulnerability curves (Table 2, Fig. 3), we evaluated the most critical embolism conditions experienced by shoots under field conditions: PLC values of $42.4 \%$ in $Q$. ilex at Mitra, and of $44.9 \%$ and $33.3 \%$ in Q. suber at Mitra and Lezirias, respectively. Even in the most critical conditions, the expected in situ maximum loss of conductivity in shoots was below $50 \%$. The estimated safety margins, above $\Psi_{x y l, 50 P L c}$, were 1.47 and $0.49 \mathrm{MPa}$ for Q. suber shoots at Lezirias and Mitra, respectively, and $0.86 \mathrm{MPa}$ for $Q$. ilex at Mitra.

\section{Discussion}

Distinct seasonal patterns of predawn leaf water potential were observed at the study sites (Lezirias and Mitra). At Mitra trees suffered a considerable water stress during the summer (Fig. 2), whereas at Lezirias $Q$. suber trees always maintained a favourable water status. Although rainfall amount and distribution varied within and between years at both sites (Fig. 1), a similar seasonal pattern of $\Psi_{l, p d}$ was observed between years at each site, reflecting the water availability near the root systems (soil and groundwater). At the end of the summer, when topsoil dries out, the water table depth was similar at both sites (see Subsection 3.1. in 
Table 3

Mean (SD) of anatomical parameters of current-year shoots of $Q$. suber and $Q$. ilex from the Lezirias and Mitra sites (three segments per tree from four trees per species site). Measured data ( $D_{\text {mean }}$, vessel density and conductive area) were tested through Analyses of Variance using linear mixed models considering species/sites as fixed effects and tree within species as a random factor. Differences between trees within species/site were not statistically significant. Statistics are not given for $D_{95}$ and $D_{h w}$ (estimated parameters)

\begin{tabular}{|c|c|c|c|c|c|}
\hline \multirow[t]{2}{*}{ Parameters } & \multicolumn{2}{|l|}{ Q. suber } & \multicolumn{3}{|l|}{ Q. ilex } \\
\hline & $\begin{array}{l}\text { Lezirias } \\
\text { (A) }\end{array}$ & $\begin{array}{l}\text { Mitra } \\
\text { (B) }\end{array}$ & $\begin{array}{l}\text { Mitra } \\
\text { (C) }\end{array}$ & $(\mathrm{A}$ and $\mathrm{B})$ & (B and $C)$ \\
\hline$D_{\text {mean }}(\mu \mathrm{m})$ & $\begin{array}{l}25.28 \\
(8.1)\end{array}$ & $\begin{array}{l}22.21 \\
(7.4)\end{array}$ & $\begin{array}{l}25.61 \\
(8.3)\end{array}$ & $\mathrm{a}$ & ns \\
\hline $\begin{array}{l}\text { Vessel density } \\
\quad\left(\text { vessel } \mathrm{mm}^{-2}\right)\end{array}$ & $\begin{array}{l}126.30 \\
(43.4)\end{array}$ & $\begin{array}{l}162.44 \\
(58.4)\end{array}$ & $\begin{array}{l}135.04 \\
(52.0)\end{array}$ & ns & ns \\
\hline $\begin{array}{l}\text { Conductive } \\
\text { area (\%) }\end{array}$ & $\begin{array}{l}6.99 \\
(2.4)\end{array}$ & $\begin{array}{l}6.99 \\
(1.9)\end{array}$ & $\begin{array}{l}7.68 \\
(1.9)\end{array}$ & ns & ns \\
\hline$D_{95}(\mu \mathrm{m})$ & $\begin{array}{l}29.23 \\
(4.4)\end{array}$ & $\begin{array}{l}25.72 \\
(4.2)\end{array}$ & $\begin{array}{l}29.11 \\
(5.0)\end{array}$ & & \\
\hline$D_{h w}(\mu \mathrm{m})$ & $\begin{array}{l}34.64 \\
(6.2)\end{array}$ & $\begin{array}{l}30.28 \\
(4.6)\end{array}$ & $\begin{array}{l}32.60 \\
(5.0)\end{array}$ & & \\
\hline
\end{tabular}

ns: non-significant

${ }^{a} P<0.05$.

Results). Hence, differences in tree water uptake mainly resulted from differences in site lithology. In fact, the sandy nature of the deep soil at Lezirias did not restrict roots from freely tapping deep water sources (groundwater). At Mitra, the harder nature of the bedrock (granite, $1 \mathrm{~m}$ below soil surface) somehow constrained the groundwater uptake by roots. The absolute seasonal minimum $\Psi_{l, m d}$ in $Q$. suber was similar at both sites (approximately $-3.0 \mathrm{MPa}$ ), regardless the variation in $\Psi_{l, p d}$. Hence, minimum leaf water potential seems to have been regulated at an almost constant species-specific minimum threshold, by a tight stomatal control.

In respect to xylem vulnerability to embolism, the fitted VCs (Eq. (1)), showed that the $50 \%$ loss in hydraulic conductivity of cur-

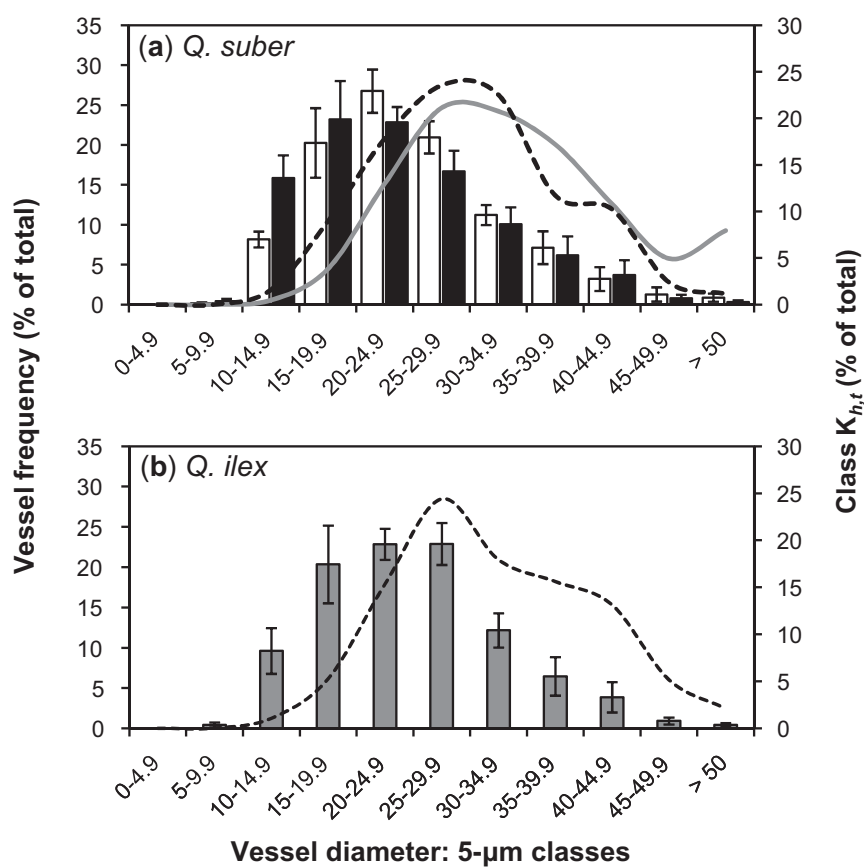

Fig. 5. Frequency distribution of the vessel diameter classes (5- $\mu \mathrm{m}$ classes) (bars) and their relative contribution to the total theoretical conductivity $\left(K_{h, t}\right)$ (lines) in shoots of (a) Q. suber from the Lezirias (open bars, full line) and Mitra (closed bars, dashed line) sites and (b) 0 . ilex from Mitra site (closed bars, dashed line). Three shoot segments per tree were sampled from four trees per species/site. Error bars are standard errors. (a) Q. suber - Lezirias: 22-Jul

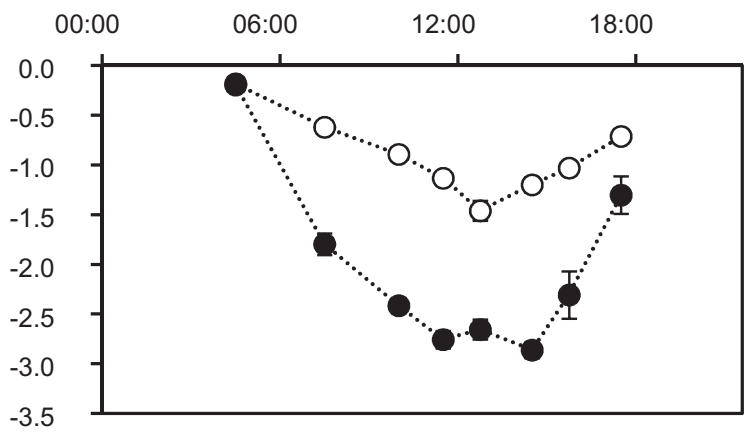

(b) Q. suber - Mitra: 08-Aug

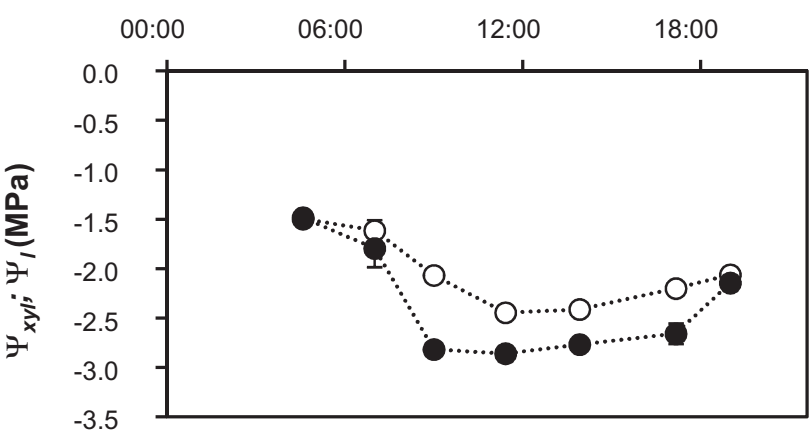

(c) Q. ilex - Mitra: 07-Aug

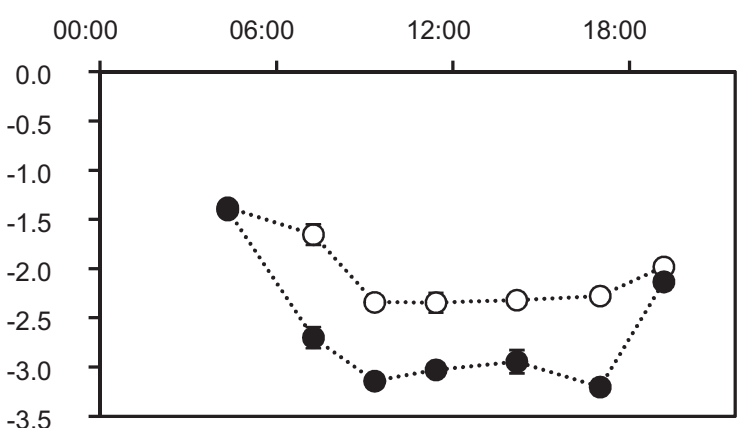

Fig. 6. Daily variation of xylem (open symbols) and leaf (closed symbols) water potential in $Q$. suber ( $a$ and $b$ ) and $Q$. ilex (c) measured in typical sunny summer days, at the Lezirias and Mitra sites. Three covered and three uncovered leaves per tree were measured in four trees per species/site. Error bars are standard errors.

rent-year shoots ( $\left.\Psi_{x y l, 50 P L C}\right)$ occurred at xylem water potentials of -2.89 and -2.94 MPa for Q. suber (Lezirias and Mitra, respectively) and -3.21 MPa for Q. ilex (Mitra) (Table 2, Fig. 3). Although the curves showed some "native" embolism $\left(P L C_{n a t}\right), \Psi_{x y l, 50 P L C}$ does not seem to depend on considering or not $P L C_{n a t}$ on the formulation of the fitting equation (Eqs. (1) and (2)) (Fig. 3). The observed $P L C_{n a t}$ may reflect the in situ level of cavitation or may result from an artefact related to air entry at branch base induced by the initial cut (if maximum vessel length exceeds total branch length). The fact that similar $P L C_{\text {nat }}$ values have been found in Q. ilex shoots (over $20 \%$ in Martínez-Vilalta et al. (2002), and over $10 \%$ in Limousin et al. (2010)) and in other Mediterranean oaks (Iovi et al., 2009) may suggest that $P L C_{n a t}$ is real and not an experimental artefact.

Xylem vulnerability to drought-induced embolism was quite similar (differences not statistically significant) both between species ( $Q$. suber and $Q$. ilex, at Mitra) or sites ( $Q$. suber at Lezirias and 


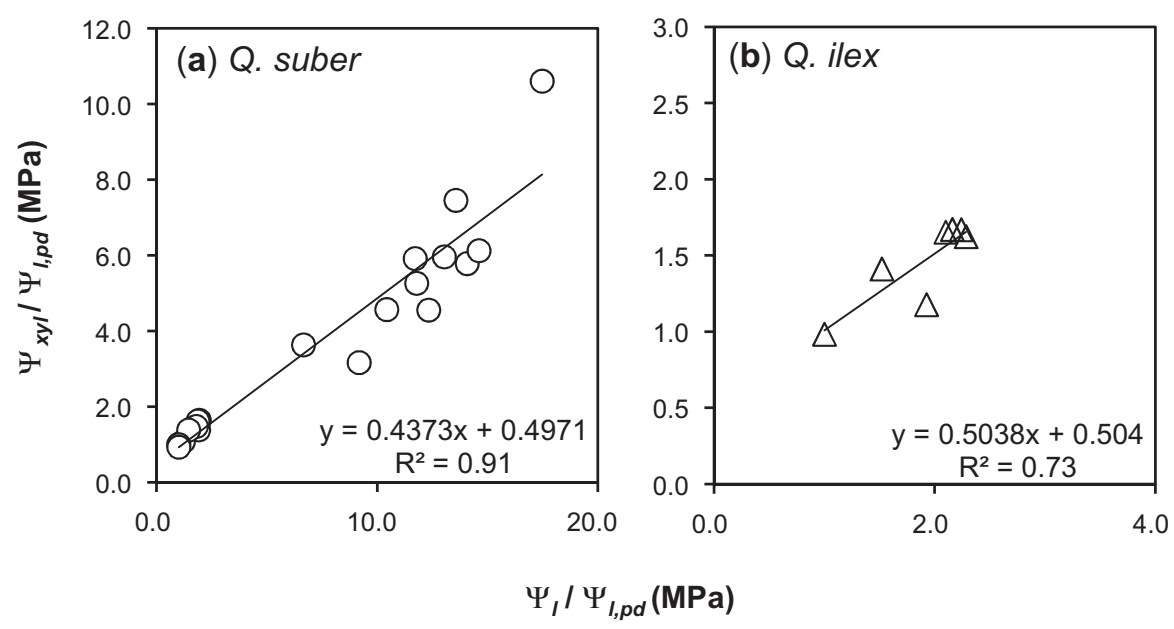

Fig. 7. Relationships between $\Psi_{x y l} / \Psi_{l, p d}$ and $\Psi_{l} / \Psi_{l, p d}$ for $Q$. suber (a) and Q. ilex (b).

Mitra) (Table 2, Fig. 3). It has been reported to be a species-specific trait, static across sites and water availability conditions (Iovi et al., 2009; Martínez-Vilalta et al., 2009; Matzner et al., 2001). However, our data suggest the existence of a between-site difference in $D_{\text {mean }}$ of $Q$. suber shoots (statistically significant), with wider vessels at the more mesic site (Lezirias) (Table 3 ). In the same species, wide vessels may be expected to have a larger amount of pit area and a greater probability of large leaky pit pores in the inter-vessel pit membranes (Jansen et al., 2009). The higher water stress at Mitra may have imposed safety constraints, reducing vessel diameter whilst maintaining $K_{s}$, vessel density and conductive area (Table 2, Table 3), i.e. narrower and safer conduits where water potentials are more negative (Sperry et al., 2008).

Mediterranean evergreen oaks, such as $Q$. suber and $Q$. ilex, are reported to be much less vulnerable to embolism than deciduous oaks from temperate climates with ring-porous wood (Tyree and Cochard, 1996). Our findings support these conclusions: $\Psi_{x y l, 50 P L C}$ values for current-year shoots of $Q$. ilex and $Q$. suber $(-3.2$ and $-2.9 \mathrm{MPa}$, or -3.4 and $-3.1 \mathrm{MPa}$ if $P L C_{n a t}$ is considered, respectively) (Table 2, Fig. 3) are more negative than those found for temperate climate oaks in North America (varying from -0.50 to $-1.89 \mathrm{MPa}$ ) (Maherali et al., 2006; Matzner et al., 2001). A wide range of $\Psi_{x y l, 50 P L C}$ values are reported for $Q$. ilex: $-2.0 \mathrm{MPa}$ (Martínez-Vilalta et al., 2002), $-3.1 \mathrm{MPa}$ (Lo Gullo and Salleo, 1993), $-3.5 \mathrm{MPa}$ (Tognetti et al., 1998), -3.6 MPa (Limousin et al., 2010), -3.2 MPa (Gartner et al., 2003), -3.0 MPa (Q. ilex subsp. ilex) and $-5.6 \mathrm{MPa}$ ( $Q$. ilex subsp. ballota) (Corcuera et al., 2004). These differences may be ascribed to: (a) different $Q$. ilex subspecies; (b) the use of seedlings or shoots of adult trees; (c) the use of different measuring techniques (dehydration vs. air injection). Vaz et al. (2012) measured a $\Psi_{x y l, 50 P L C}$ of $-5.0 \mathrm{MPa}$ for shoots/stems of cork oak seedlings, in the lowest range of the values observed for $Q$. ilex. Irrespective of the fitted equations (see Fig. 3), our estimates of $\Psi_{x y l, 50 P L C}$ for $Q$. ilex and $Q$. suber shoots are in the same range of those published for adult $Q$. ilex trees (e.g. Limousin et al., 2010; Tognetti et al., 1998), but are less negative than those reported by Tyree and Cochard (1996) for both species. Interestingly, the lowest recorded $\Psi_{x y l, 50 P L C}$ values for both $Q$. ilex and $Q$. suber were observed in seedlings (Corcuera et al., 2004; Vaz et al., 2012). Since seedlings have not yet a deep root system, they probably need to be more drought-tolerant than adult trees, i.e. less vulnerable to embolism. A lower vulnerability to cavitation in seedlings than in adult trees has been reported for Q. ilex (Lo Gullo and Salleo, 1993), Q. wislizenii (Matzner et al., 2001), Eucalyptus crebra and Eucalyptus xanthoclada (Rice et al., 2004). This may impact on seedling survival and natural regeneration. Adult trees with fully devel- oped roots may access deep water sources buffering the seasonal water deficits (Canadell et al., 1996; David et al., 2007).

Wood anatomy of shoots of $Q$. ilex and $Q$. suber showed solitary, circular to elliptical vessels arranged in a diagonal to radial pattern (Fig. 4), which is consistent to that reported in other studies for the same species (Corcuera et al., 2004; Leal et al., 2008). Vessel diameter frequency distribution approached a unimodal pattern (Fig. 5) in shoots of both species (more evident in $Q$. suber), suggesting a diffuse-type porosity, as reported by Gartner et al. (2003), Leal et al. (2008) and Villar-Salvador et al. (1997). This is also corroborated by the difference between $D_{\text {mean }}$ and $D_{95}$ for shoots of both species, 14-16\%, indicating a small difference between the size of early and latewood vessels (Tyree et al., 1994).

In $K_{s, t}$ calculations all vessels were assumed to be functional. As expected, measured $K_{s}$ was lower than $K_{s, t}$ since the theoretical conductivity was calculated neglecting non-functional vessels and the resistance between vessels (Sellin et al., 2008). Xylem conducting efficiency $\left(K_{s} / K_{s, t}\right)$ of the two oaks was similar, and values agree well with those previously published for $Q$. ilex (Limousin et al., 2010). This is a further indication that $P L C_{n a t}$ is probably not an experimental artefact and that some vessels are not functional anymore.

According to Hacke et al. (2000) the resistance to cavitation may adjust to the amount of drought experienced in situ. However, the non-significant difference in xylem vulnerability to embolism found between $Q$. ilex at the Mitra site and $Q$. suber at the Mitra and Lezirias sites suggests that this hydraulic trait does not explain per se the current geographical distribution of the two species: $Q$. ilex prevailing in more xeric areas compared to $Q$. suber. Additional mechanisms of drought tolerance/avoidance may probably be more relevant. For instance, rooting depth may play an important role since it is known that Mediterranean evergreen oaks rely on deep roots to cope with the summer drought (Canadell et al., 1996; Maherali et al., 2004). A previous study on sap flow and predawn leaf water potential of co-occurring adult $Q$. suber and $Q$. ilex trees at the same site (Mitra) showed that $Q$. ilex trees were able to maintain a higher water status and transpiration during the summer drought compared to Q. suber (David et al., 2007). This was ascribed to a deeper and more efficient root system in $Q$. ilex.

Aiming at the evaluation of the in situ safety margins of shoots above cavitation thresholds, we estimated the long-term patterns of variation of xylem water potential (Fig. 7). Unlike $\Psi_{l, m d}$, the minimum value of xylem water potential in shoots does not seem to be maintained to a constant level across sites but depends both on stomatal regulation and on $\Psi_{l, p d}$ (Figs. 6 and 7). $\Psi_{x y l}$ is usually con- 
sidered a better estimator of plant water status than $\Psi_{l, m d}$ (Choné et al., 2001).

The comparison between the predicted minimum $\Psi_{x y l}$ under field conditions and $\Psi_{x y l, 50 P L C}, \Psi_{x y l, 75 P L C}$ and $\Psi_{x y l, 99 P L C}$ (Table 2, Fig. 3) suggests that shoots of both species live, at both sites, with a large hydraulic safety margin, above these embolism thresholds. The minimum safety margins observed in shoots of both species above the $\Psi_{x y l, 50 \text { PLC }}$ were similar at Mitra, although slightly higher for $Q$. ilex. The hydraulic safety margins were higher in $Q$. suber shoots at the Lezirias site due to the more favourable tree water status. Wide hydraulic safety margins are a likely protection mechanism, preventing embolism from occurring in organs where it may be more damaging (like stems) or where its reversal is less efficient (like shoots) (Nardini and Salleo, 2000; Pockman and Sperry, 2000). Martínez-Vilalta et al. (2002) have observed in Q. ilex

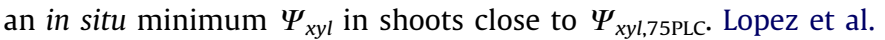
(2005) found that, under field conditions, several tropical trees usually lived with minimum shoot $\Psi_{x y l}$ between $\Psi_{x y l, 50 P L C}$ and $\Psi_{x y l, 75 \text { PLc. }}$ Therefore, at our sites, the studied oak trees seem very well adapted, operating with larger safety margins than those usually reported.

We believe that our results are relevant to the understanding of survival, growth, and functional behaviour of evergreen oaks in Mediterranean-type climates, subject to recurrent/seasonal drought conditions.

\section{Acknowledgements}

This work was supported by the Portuguese Foundation for Science and Technology (FCT) (projects POCI-PTDC/AGR/59152/2004). Clara A. Pinto was funded by a doctoral grant from FCT (SFRH/BD/ 46479/2008). We thank Rui Alves and Vitor Barros (Companhia das Lezirias) for providing site facilities, Joaquim Mendes (ISA) for assistance in the field work, and Cristiana Duarte (FLOR/IICT) for help in the anatomy work. We also thank the two anonymous Reviewers for the helpful and constructive comments on the manuscript.

\section{References}

Bugalho, M.N., Caldeira, M.C., Pereira, J.S., Aronson, J., Pausas, J.G., 2011. Mediterranean cork oak savannas require human use to sustain biodiversity and ecosystem services. Front. Ecol. Environ. 9 (5), 278-286.

Canadell, J., Jackson, R.B., Ehleringer, J.R., Mooney, H.A., Sala, O.E., Schulze, E.D., 1996. Maximum rooting depth of vegetation types at the global scale. Oecologia $108,583-595$

Choat, B., Drayton, W.M., Brodersen, C., Matthews, M.A., Shackel, K.A., Wada, H., McElrone, A.J., 2010. Measurement of vulnerability to water stress-induced cavitation in grapevine: a comparison of four techniques applied to longvesseled species. Plant, Cell Environ. 33, 1502-1512.

Choné, X., van Leeuwen, C., Dubourdieu, D., Gaudillère, J.P., 2001. Stem water potential is a sensitive indicator of grapevine water status. Ann. Bot. 87, 477483.

Cochard, H., Damour, G., Bodet, C., Tharwat, I., Poirier, M., Améglio, T., 2005. Evaluation of a new centrifuge technique for rapid generation of xylem vulnerability curves. Physiol. Plant. 124, 410-418.

Corcuera, L., Camarero, J.J., Gil-Pelegrín, E., 2004. Effects of a severe drought on Quercus ilex radial growth and xylem anatomy. Trees - Struct. Funct. 18, 83-92.

David, T.S., Henriques, M.O., Kurz-Besson, C., Nunes, J., Valente, F., Vaz, M., Pereira, J.S., Siegwolf, R., Chaves, M.M., Gazarini, L.C., David, J.S., 2007. Water strategies in two co-occurring Mediterranean evergreen oaks: surviving the summer drought. Tree Physiol. 27, 793-803.

FAO, 1988. FAO/UNESCO Soil Map of the World. Revised Legend, with Corrections. World Soil Resources Report 60. FAO, Rome (Reprinted as Technical Paper 20, ISRIC, Wageningen, 1994).

Gartner, B.L., Roy, J., Huc, R., 2003. Effects of tension wood on specific conductivity and vulnerability to embolism of Quercus ilex seedlings grown at two atmospheric $\mathrm{CO}_{2}$ concentrations. Tree Physiol. 23, 387-395.

Hacke, U.G., Sperry, J.S., Pittermann, J., 2000. Drought experience and cavitation in six shrubs from the Great Basin, Utah. Basic Appl. Ecol. 1, 31-41.

INMG, 1991a. O clima de Portugal. Normais climatológicas da Região Alentejo e Algarve, correspondentes a 1951-1980, Fascículo XLIX, vol. 4-4 a região. Instituto Nacional de Meteorologia e Geofísica, Lisboa.
INMG, 1991b. O clima de Portugal. Normais climatológicas da Região Ribatejo e Oeste, correspondentes a 1951-1980, Fascículo XLIX, vol. 2-2 região. Instituto Nacional de Meteorologia e Geofísica, Lisboa.

Iovi, K., Kolovou, C., Kyparissis, A., 2009. An ecophysiological approach of hydraulic performance for nine Mediterranean species. Tree Physiol. 29, 889-900.

Jansen, S., Choat, B., Pletsers, A., 2009. Morphological variation of intervessel pit membranes and implications to xylem function in angiosperms. Am. J. Bot. 96 (2), 409-419.

Leal, S., Nunes, E., Pereira, H., 2008. Cork oak (Quercus suber L.) wood growth and vessel characteristics variations in relation to climate and cork harvesting. Eur. J. Forest Res. 127, 33-41.

Limousin, J.M., Longepierre, D., Huc, R., Rambal, S., 2010. Change in hydraulic traits of Mediterranean Quercus ilex subjected to long-term throughfall exclusion. Tree Physiol. 30, 1026-1036.

Lloret, F., Siscart, D., Dalmases, C., 2004. Canopy recovery after drought dieback in holm-oak Mediterranean forests of Catalonia (NE Spain). Global Change Biol. 10, 2092-2099.

Lo Gullo, M.A., Salleo, S., 1993. Different vulnerabilities of Quercus ilex L. to freezeand summer drought-induced xylem embolism: an ecological interpretation. Plant, Cell Environ. 16, 511-519.

Lo Gullo, M.A., Salleo, S., Rosso, R., Trifilò, P., 2003. Drought resistance of 2-year-old saplings of Mediterranean forest trees in the field: relations between water relations, hydraulics and productivity. Plant Soil 250, 259-272.

Lopez, O.R., Kursar, T.A., Cochard, H., Tyree, M.T., 2005. Interspecific variation in xylem vulnerability to cavitation among tropical tree and shrub species. Tree Physiol. 25, 1553-1562.

Maherali, H., Pockman, W.T., Jackson, R.B., 2004. Adaptive variation in the vulnerability of woody plants to xylem cavitation. Ecology 85 (8), 2184-2199.

Maherali, H., Moura, C.F., Caldeira, M.C., Wilson, C.J., Jackson, R.B., 2006. Functional coordination between leaf gas exchange and vulnerability to xylem cavitation in temperate forest trees. Plant, Cell Environ. 29, 571-583.

Martínez-Vilalta, J., Prat, E., Oliveras, I., Piñol, J., 2002. Xylem hydraulic properties of roots and stems of nine Mediterranean woody species. Oecologia 133, 19-29.

Martínez-Vilalta, J., Cochard, H., Mencuccini, M., Sterck, F., Herrero, A., Korhonen, J.F.J., Llorens, P., Nikinmaa, E., Nolé, A., Poyatos, R., Ripullone, F., Sass-Klaassen, U., Zweifel, R., 2009. Hydraulic adjustment of Scots pine across Europe. New Phytol. 184, 353-364.

Matzner, S.L., Rice, K.J., Richards, J.H., 2001. Intra-specific variation in xylem cavitation in interior live oak (Quercus wislizenii). J. Exp. Bot. 52 (357), 783-789.

McDowell, N.G., Beerling, D.J., Breshears, D.D., Fisher, R.A., Raffa, K.F., Stitt, M., 2011. The interdependence of mechanisms underlying climate-driven vegetation mortality. Trends Ecol. Evol. 26 (10), 523-532.

Miranda, P., Coelho, F.E.S., Tomé, A.R., Valente, M.A., 2002. 20th Century Portuguese climate and climate change scenarios. In: Santos, F.D., Forbes, K., Moita, R. (Eds.), Climate Change in Portugal. Scenarios, Impacts and Adaptation Measures. Gradiva, Lisboa, pp. 25-83.

Nardini, A., Salleo, S., 2000. Limitation of stomatal conductance by hydraulic traits: sensing or preventing xylem cavitation? Trees - Struct. Funct. 15, 14-24.

Ogle, K., Barber, J.J., Willson, C., Thompson, B., 2009. Hierarchical statistical modeling of xylem vulnerability to cavitation. New Phytol. 182, 541-554.

Pammenter, N.W., Vander Willigen, C., 1998. A mathematical and statistical analysis of the curves illustrating vulnerability of xylem cavitation. Tree Physiol. 18, 589-593.

Pinto, C.A., Henriques, M.O., Figueiredo, J.P., David, J.S., Abreu, F.G., Pereira, J.S., Correia, I., David, T.S., 2011. Phenology and growth dynamics in Mediterranean evergreen oaks: effects of environmental conditions and water relations. For. Ecol. Manage. 262, 500-508.

Pockman, W.T., Sperry, J.S., 2000. Vulnerability to xylem cavitation and the distribution of Sonoran desert vegetation. Am. J. Bot. 87 (9), 1287-1299.

Rice, K.J., Matzner, S.L., Byer, W., Brown, J.R., 2004. Patterns of tree dieback in Queensland, Australia: the importance of drought stress and the role of resistance to cavitation. Oecologia 139, 190-198.

Ryan, M.G., 2011. Tree responses to drought. Tree Physiol. 31, 237-239.

Scholander, P.F., Hammel, H.T., Bradstreet, E.D., Hemmingsen, E.A., 1965. Sap pressure in vascular plants. Science 148, 339-346.

Sellin, A., Rohejärv, A., Rahi, M., 2008. Distribution of vessel size, vessel density and xylem conducting efficiency within a crown of silver birch (Betula pendula). Trees - Struct. Funct. 22, 205-216.

Snedecor, G.W., Cochran, W.G., 1978. Statistical Methods, sixth ed. The Iowa State University Press, Ames.

Sperry, J.S., 1986. Relationship of xylem embolism to xylem pressure potential, stomatal closure, and shoot morphology in palm Rhapis excelsa. Plant Physiol. $80,110-116$.

Sperry, J.S., Donnelly, J.R., Tyree, M.T., 1988. A method for measuring hydraulic conductivity and embolism in xylem. Plant, Cell Environ. 11, 35-40.

Sperry, J.S., Nichols, K.L., Sullivan, J.E.M., Eastlack, S.E., 1994. Xylem embolism in ring-porous, diffuse-porous and coniferous trees of northern Utah and interior Alaska. Ecology 75 (6), 1736-1752.

Sperry, J.S., Meinzer, F.C., McCulloh, K.A., 2008. Safety and efficiency conflicts in hydraulic architecture: scaling from tissues to trees. Plant, Cell Environ. 31, 632-645.

Sperry, J.S., Christman, M.A., Torres-Ruiz, J.M., Taneda, H., Smith, D.D., 2012. Vulnerability curves by centrifugation: is there an open vessel artefact, and are ' $r$ ' shaped curves necessarily invalid? Plant, Cell Environ. 35, 601-610.

Tognetti, R., Longobucco, A., Raschi, A., 1998. Vulnerability of xylem to embolism in relation to plant hydraulic resistance in Quercus pubescens and Quercus ilex co- 
occurring in a Mediterranean coppice stand in central Italy. New Phytol. 139, 437-447.

Tyree, M.T., Cochard, H., 1996. Summer and winter embolism in oak - impact on water relations. Ann Sci Forest 53, 173-180.

Tyree, M.T., Sperry, J.S., 1988. Do woody plants operate near the point of catastrophic xylem dysfunction caused by dynamic water stress? Plant Physiol. 88, 574-580.

Tyree, M.T., Zimmermann, M.H., 2002. Xylem structure and the ascent of sap. In: Tyree, M.T. (Ed.), Springer Series in Wood Science, second ed. Springer-Verlag, Berlin.

Tyree, M.T., Davis, S.D., Cochard, H., 1994. Biophysical perspectives of xylem evolution: is there a trade-off of hydraulic efficiency for vulnerability to dysfunction? IAWA J. 15 (4), 335-360.

van Mantgem, P.J., Stephenson, N.L., Byrne, J.C., Daniels, L.D., Franklin, J.F., Fule, P.Z., Harmon, M.E., Larson, A.J., Smith, J.M., Taylor, A.H., Veblen, T.T., 2009.
Widespread increase of tree mortality rates in the Western United States. Science 323, 521-524.

Vaz, M., Cochard, H., Gazarini, L., Graça, J., Chaves, M.M., Pereira, J.S., in press. Cork oak (Quercus suber L.) seedlings acclimate to elevated $\mathrm{CO}_{2}$ and water stress: photosynthesis, growth, wood anatomy and hydraulic conductivity. Trees Struct. Funct. doi: http://dx.doi.org/10.1007/s00468-012-0691-X.

Villar-Salvador, P., Castro-Díez, P., Pérez-Rontomé, C., Montserrat-Martí, G., 1997. Stem xylem features in three Quercus (Fagaceae) species along a climatic gradient in NE Spain. Trees - Struct. Funct. 12, 90-96.

Wullschleger, S.D., Meinzer, F.C., Vertessy, R.A., 1998. A review of whole-plant water use studies in trees. Tree Physiol. 18, 499-512.

Zar, J.H., 1996. Biostatistical Analysis, third ed. Prentice Hall International, New Jersey.

Zimmermann, M.H., Jeje, A.A., 1981. Vessel-length distribution in some American woody plants. Can. J. Bot. 59, 1882-1892. 